\title{
Exploration of Mathematics Teacher Education Curriculum in Local Undergraduate Colleges Based on the National Teachers' Qualification Examination
}

\author{
Zhijun Luo ${ }^{1, a, ~}$, Lirong Wang ${ }^{2, b}$, and Xiaolian Liao ${ }^{1, c}$ \\ ${ }^{1}$ School of Mathematics and Finance, Hunan University of Humanities, Science and Technology, \\ Loudi 417000, China \\ ${ }^{2}$ School of Information, Hunan University of Humanities, Science and Technology, Loudi 417000, \\ China. \\ aldlzj123@163.com, ${ }^{b}$ Idwlr1234@163.com, ${ }^{c}$ hnldlxl2005@126.com
}

Keywords: National Teachers' Qualification Examination; mathematics teacher education curriculum; local undergraduate colleges

\begin{abstract}
This paper, under the background of the National Teachers' Qualification Examination, focuses on setting up of mathematics teacher education courses in local undergraduate colleges, investigates the current situation of mathematics teacher education curriculum setting, analyzes the existing problems and causes, and tries to proposes improvement strategies.
\end{abstract}

\section{Introduction}

As the first threshold for the selection of qualified teachers, the national teacher's qualification examination system is an important part of the teacher qualification system. Its implementation plays an important role in improving the level of teachers, improving the status of teachers, and ensuring the quality of teachers. According to the requirements of the Ministry of Education of China, in 2015, the teacher's qualification examination system was fully implemented, which raises the entry threshold for teachers and breaks the lifelong system of teacher qualifications and implements a regular registration system. At the same time, the privilege of the normal school students automatically obtaining teacher qualifications disappears. In this way, normal school students are in a passive position in the acquisition of teacher qualifications, which requires that the teacher education majors adjust the current teacher education curriculum system. Such as Zhu [1] pointed out that the original talent training scheme should be optimized, following the principle of "putting students first, meeting demands, according to standards, emphasizing the outline, following laws, making overall plans, and whole inheritance with proper fine-tuning". For more discussion see [2]-[5].

On the other hand, the phenomenon of the marginalization of normal education exists in the process of the transformation and development in local undergraduate colleges and universities, 
resulting in the loss of teacher characteristics in some local universities. Song [6] considers that local undergraduate colleges and universities, as an important part of China's higher education system, should be based on the actual needs of local economic and social development, and deal with the relationship between the normal nature, the academic nature and the application. Hence, it is helpful for the normal students to pass the examination of teachers' qualification by analyzing the influence of national examination of teacher qualification certificate on normal students(especially the normal students in local universities). At the same time, through the optimization of education courses etc, it will help improve normal students' core qualities and competitiveness.

\section{Investigation and Analysis}

\section{Section Headings}

The participants were mathematics normal school students in our university. Of the 136 students, 120 participated (88\% response rate). 67(55.8\%) were female students and fifty-three (44.2\%) were male students.

\section{Q1 Do you know about the national teachers' qualification examination NTQE?}

Table 1 Q1 survey results

\begin{tabular}{|l|l|l|l|l|l|}
\hline \multicolumn{1}{|c|}{ Item } & Freshman & Sophomore & Junior & Senior & $\begin{array}{l}\text { Percentage of } \\
\text { total number }\end{array}$ \\
\hline A .don't know & 12 & 16 & 2 & 0 & $25 \%$ \\
\hline B. know a bit & 18 & 24 & 8 & 8 & $48.33 \%$ \\
\hline C. very familiar & 0 & 5 & 15 & 12 & $26.67 \%$ \\
\hline
\end{tabular}

The above questionnaire survey data shows that $26.67 \%$ of the students in the random sample survey are very familiar with the national teachers' qualification examination system, a quarter of the students are not very clear about the "national exam" new system, mainly focusing on first-grade and second-grade students. The reason for this is that students' awareness of their own conceptions is not enough. On the other hand, the publicity of the school is not enough.

Q2 Are you satisfied with the teacher education curriculum?

A. Very satisfied B. Satisfied C. Ordinary D. Not satisfied E. Very unsatisfied

\section{satisfaction questionnaire}

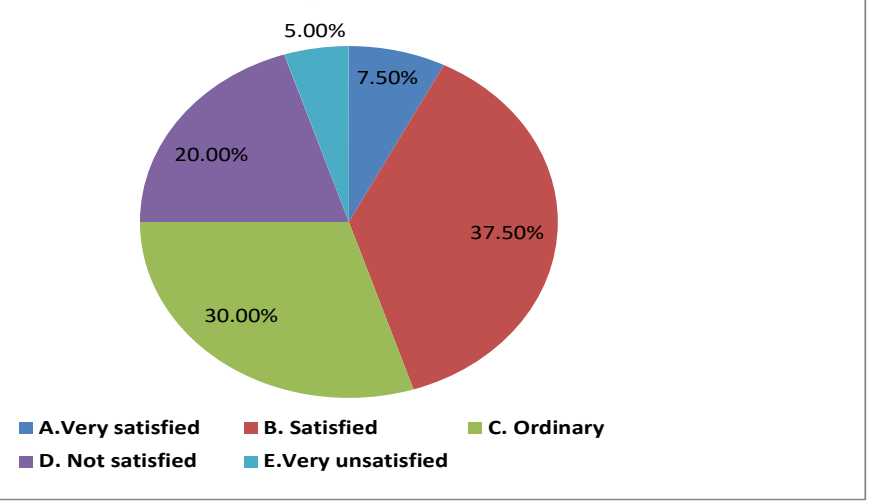

Fig. 1 The results of the satisfaction survey

The pie graph shows that only $45 \%$ of students are satisfied with the teacher education curriculum, of which very satisfied are less than $10 \%$. Reasons for dissatisfaction we can get some results from students answering the following Question 3.

Q3 The reason for your dissatisfaction is [multiple choice] 
Table 2 Q3 survey results

\begin{tabular}{|l|l|l|}
\hline \multicolumn{1}{|c|}{ Item } & Sub-total & Percentage \\
\hline A. The way of teaching and learning is too single & 75 & $62.5 \%$ \\
\hline B. The contents learned are empty and out of reality & 56 & $46.67 \%$ \\
\hline C. The proportion of required courses is too heavy & 46 & $38.33 \%$ \\
\hline D. Course content is backward, knowledge is old & 45 & $37.5 \%$ \\
\hline E. Weak practical curriculum & 62 & $51.67 \%$ \\
\hline F. Teacher's quality is not high & 30 & $25 \%$ \\
\hline G. Insufficient emphasis on teaching skills & 25 & $20.83 \%$ \\
\hline Effectively fill in the person times & 120 & \\
\hline
\end{tabular}

The above table shows that students complain most about single teaching methods, and secondly they think that practice teaching is weak. From those we can see that the teaching methods in the teacher education curriculum still based on the conventional teaching methods. Students expect that teachers will adopt other new teaching methods that can reflect practicality and outstanding application.

Q4 What kind of knowledge do you think you lack in current learning? [multiple choice]

Table 3 Q4 survey results

\begin{tabular}{|l|l|l|}
\hline \multicolumn{1}{|c|}{ Item } & Sub-total & Percentage \\
\hline A. Subject expertise & 41 & $34.17 \%$ \\
\hline B. Comprehensive knowledge of education & 62 & $51.67 \%$ \\
\hline C. Teaching skills and abilities & 75 & $62.5 \%$ \\
\hline D. Teaching practice experience & 82 & $68.33 \%$ \\
\hline E. Classroom management experience & 71 & $59.17 \%$ \\
\hline Effectively fill in the person times & 120 & \\
\hline
\end{tabular}

As can be seen from the table, almost $70 \%$ of students think that they lack teaching practice experience. And $62.5 \%$ of students consider that their teaching skills and skills need to be improved. In addition, we can see from the table that students have high requirements for their teaching practice ability.

\section{Suggestion}

Under the background of the national teacher's qualification examination, the course setting of normal students is not connected with the content of teachers' qualification examination, the proportion of the theoretical course is larger, the teaching practice needs to be perfected and so on, which affects the passing rate of teachers' qualification certificate for normal students. We propose to improve the mathematics teacher education curriculum from the following aspects:

\subsection{Adjustment of Teacher Education Curriculum System}

According to the requirements of the examination syllabus, the system of teacher education curriculum is rebuilt. The system should include three modules: general education, subject professional and practical teaching, and pay attention to the balance between those. At the same time, we can set up some new courses, such as: The teacher qualification affairs, Research on basic education reform, Teachers' professional ethics and professional growth, Class management, etc. 


\subsection{Strengthen the Practice Teaching}

Practical lessons are important way for normal students to connect theory with practice, to master practical teaching ability and to improve overall quality. According to the new teacher qualification examination system, we should increase the class hours and credits of teaching practice courses, establish a reasonable mechanism for classroom observation and educational internship, actively carry out practical activities such as special competitions and simulation teaching etc, so as to improve students' teaching practice ability.

In addition, we must change the single teaching mode and introduce new teaching modes based on internet information technology such as massive open online course(MOOC), micro course and flipped classroom. Considering that university teachers are not familiar with middle school mathematics textbooks and weak in teaching strategy. It is suggested that middle school teachers should be employed as the instructor of normal students' simulation classroom teaching and training.

On the way of assessment, the multiple evaluation and evaluation system is formed for "formative, diagnostic, and summative assessments". Our principles of assessment will mainly be to stimulate students to work hard and produce deep level learning.

\section{Conclusion}

This paper studies the setting up of mathematics teacher education curriculum in local undergraduate colleges under the background of national qualification examination. First, it investigates the current situation of curriculum education, and then puts suggestions for improvement from the aspects of adjusting curriculum structure, strengthening practical teaching and reforming teaching methods etc. The purpose is to enable students to adapt to basic education teaching requirements and quickly grow into a qualified basic education math teacher.

\section{Acknowledgments}

This work was supported in part by the fund of higher education in Hunan Province ([2015]291. NO.449, [2017]452. NO.469,) and the Educational Reform Research Fund of Hunan University of Humanities, Science, and Technology (No. RKJGY1526, 1628 ,1629).

\section{References}

[1] Zhu P Y. Study on the optimization of teacher training program for normal education under the background of teacher qualification examination, Teacher Education Forum. 3(2017)5-8.

[2] Wang J. The influence of national teacher qualification exam on pre service teacher education, Journal of Higher Education Management. 9(2015)105-109.

[3] Zhong H, Liming X U. Discussion on pre-service teacher education quality outlook: against the background of normal graduates' national teachers' qualification examinations and open teachers' recruitment test, Journal of Teacher Education. 3(2016) 26-32.

[4] Liu Y. The reform of teachers' qualification certification system impact on the integration of teacher education, Journal of Liaoning Educational Administration Institute. 34(2017)24-27.

[5] Cao X T, Cheng Y W, Liang Z B, et al. Discussion on the comprehensive quality of normal school students cultivation under the new teacher qualification examination system, Journal of Jimei University. 18(2017)1-4.

[6] Song Z H. The transformation development of normal universities: the trend, reflection and exploration, Journal of National Academy of Education Administration. 2(2018)10-16. 